\title{
Prolonged zidovudine administration induces a moderate increase in the growth and steroidogenic capacity of the rat adrenal cortex
}

\author{
CINZIA TORTORELLA ${ }^{1}$, DIEGO GUIDOLIN ${ }^{1}$, LUCIA PETRELLI ${ }^{1}$, RENZO DE TONI ${ }^{2}$, \\ ORNELLA MILANESI $^{3}$, EZIA RUGA ${ }^{3}$, PIERA REBUFFAT ${ }^{1}$ and SERGIO BOVA ${ }^{4}$ \\ Departments of ${ }^{1}$ Human Anatomy and Physiology; ${ }^{2}$ Clinical and Experimental Medicine; ${ }^{3}$ Pediatrics; \\ ${ }^{4}$ Pharmacology and Anesthesiology, School of Medicine, University of Padua, I-35121 Padua, Italy
}

Received December 11, 2008; Accepted February 26, 2009

DOI: 10.3892/ijmm_00000195

\begin{abstract}
Zidovudine (AZT) is an antiretroviral drug widely used in the treatment of human immunodeficiency virus (HIV)infected patients, whose prolonged administration was found to cause toxic lesions in cardiomyocytes in humans and experimental animals. Alterations in adrenocortical secretion were frequently observed in HIV patients, but it is not clear whether medication is involved in the production of these complications. Hence, we studied in vivo and in vitro, the effects of AZT on the rat adrenal cortex. The prolonged AZT administration (100 mg/kg per day for 4 months) did not cause overt qualitative morphological alterations of adrenocortical cells, which, however, underwent a net hypertrophy. Hypertrophy is associated with increases in the volume and surface area per cell of the mitochondrial compartment and smooth endoplasmic reticulum (where the enzymes of steroid synthesis are located), and a marked decrease in the volume of the lipiddroplet compartment (where cholesterol and its esters, the precursors of steroid hormones, are stored). AZT chronic treatment induced rises in the plasma concentrations of aldosterone and corticosterone, and in the basal and ACTHstimulated in vitro secretion of these hormones from adrenal slices. The 24-h exposure to AZT $\left(10^{-5} \mathrm{M}\right)$ did not significantly affect either secretory activity or proliferation and apoptotic rates of cultured rat adrenocortical cells. Taken together, these findings suggest that AZT chronic treatment enhances the growth and steroidogenic capacity of rat adrenal cortex, probably by activating the central branch of the hypothalamicpituitary-adrenal axis. The toxic activity of AZT is thought to depend on increased production of ROS. On these grounds, it is likely that the lack of toxic effect of AZT on adrenocortical cells is due to their very elevated content in vitamin $\mathrm{C}$, which
\end{abstract}

Correspondence to: Dr Diego Guidolin, Department of Human Anatomy and Physiology, Section of Anatomy, Via A. Gabelli 65, I-35121 Padua, Italy

E-mail: diego.guidolin@unipd.it

Key words: zidovudine, adrenal cortex, steroid-hormone secretion, rat prevents the deleterious effect of the AZT-induced increase in intracellular ROS production.

\section{Introduction}

Adrenal insufficiency is a well known complication in advanced stages of human immunodeficiency virus (HIV) infection, and the prolonged medication is suspected to be involved in its pathogenesis (reviewed in refs. 1-3). In fact, ketoconazole inhibits adrenal steroidogenesis, rifampin enhances cortisol metabolism and megestrol acetate suppresses pituitary ACTH secretion. In contrast, early stages of HIV infection are frequently associated with a marked rise in both basal and ACTH-stimulated cortisol blood levels (3-6). However, it is not known whether antiretroviral therapy is involved, at least in part, in the production of hypercortisolemia.

Zidovudine (AZT) is a widely used drug in the treatment of patients with acquired immune deficiency syndrome (AIDS) (7). Several studies have shown that prolonged administration of AZT induces heart toxicity both in humans and experimental animals, mainly due to mitochondrial dysfunctions in myocardiocytes (8-12), but the effects of this drug on adrenal function have not yet been studied. Therefore, it seems important to investigate, in vivo and in vitro, the effects of AZT on the structure and function of the adrenal cortex in the rat, in order to evaluate the possibility that adrenal dysfunction occurring in HIV patients is, at least partly, a side-effect of the therapy with this antiretroviral drug.

\section{Materials and methods}

Reagents and animals. AZT was purchased from Glaxo Smith Kline (Verona, Italy), ACTH from Phoenix Pharmaceuticals (Belmont, CA) and medium 199 from Difco (Detroit, MI). Pure idrosoluble 3'-azido-3'-deoxythymidine (AZT), doxorubicin, 5-bromo-2'-deoxyuridine (BrdU), 4',6'-diamine-2'-phenilindole (DAPI), Dulbecco's modified Eagle's medium (DMEM), fetal calf serum (FCS), bovine serum albumin (BSA), and all other laboratory reagents were provided by Sigma-Aldrich Corporation (St. Louis, MO). Wistar Kyoto male rats were obtained from Charles-River (Como, Italy). 

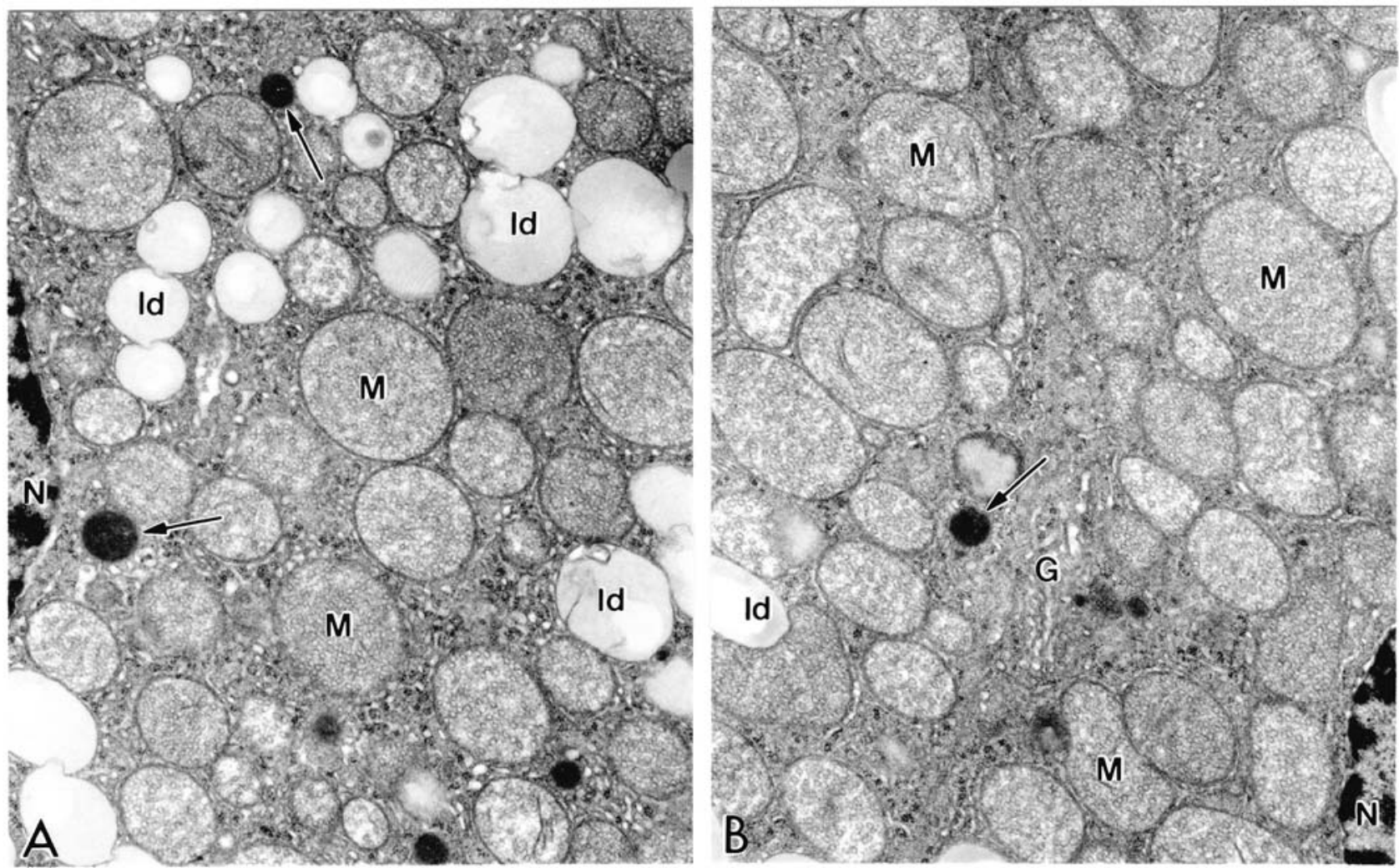

Figure 1. Electron micrographs of ZF cells of control (A) and AZT-treated rat adrenal cortex (B). AZT induces a marked decrease in the number of lipid droplets (ld), without altering other ultrastructural features of cells. N, nucleus; M, mitochondria; G, golgi apparatus; arrows, dense bodies (lysosomes). Magnification, x12,000.

Study protocol. Sixteen rats (weighing 300-350 g at the beginning of treatment) were housed in temperature- and humidity-controlled conditions, exposed to a 12-h light/dark cycle, and given tap water ad libitum and standard chow. Rats were divided into two equal groups. One group was treated with AZT (100 mg/kg per day) dissolved in drinking water $(11,12)$ for 4 months, and the other group was untreated and served as a control. Animals were decapitated at 11:00 a.m., and their trunk blood was collected with apoprotin $(70 \mathrm{mg} / \mathrm{ml})$ and EDTA $(1 \mathrm{mg} / \mathrm{ml})$; plasma was separated and stored at $-80^{\circ} \mathrm{C}$. Adrenal glands were removed and freed of pericapsular fat; the left gland was processed for light and electron microscopy, and the right one was immediately used for in vitro studies. Adrenals of other 12 untreated rats were used to obtain primary adrenocortical cell cultures. The study protocol was approved by the local Ethics Committee for Biomedical Studies, and the investigation was carried out according to the Guide for the Care and Use of Laboratory Animals (US National Institutes of Health; publication No. 58, revised 1996).

Incubation of adrenal slices. Right adrenals from control and AZT-treated rats were halved, and each half was cut into thick slices (13). Slices were placed in medium 199 and Krebs-Ringer bicarbonate buffer with $0.2 \%$ glucose, containing $5 \mathrm{mg} / \mathrm{ml}$ BSA. The samples were incubated $(4-5 \mathrm{mg} / \mathrm{ml})$ in the presence or absence of $10^{-9} \mathrm{M}$ ACTH. The incubation was carried out for $180 \mathrm{~min}$ in a shaking bath at $37^{\circ} \mathrm{C}$ in an atmosphere of $95 \%$ air and $5 \% \mathrm{CO}_{2}$. At the end of the experiment, the incubation medium was collected and kept at $-80^{\circ} \mathrm{C}$.
In vitro culture. Adrenals from untreated rats were halved, enucleated to remove medulla and chopped into small fragments under sterile conditions. Dispersed adrenocortical cells were obtained by sequential enzymatic digestion and mechanical disaggregation (14). Dispersed cells were seeded at density of $2 \times 10^{4}$ cells $/ \mathrm{cm}^{2}$ in 24-well polystirene plates, and cultured for $72 \mathrm{~h}$ at $37^{\circ} \mathrm{C}$ in DMEM (added to $1.125 \mathrm{~g} / 1$ sodium bicarbonate, $10 \% \mathrm{FCS}, 100 \mathrm{U} / \mathrm{ml}$ penicillin and $100 \mu \mathrm{g} / \mathrm{ml}$ streptomycin) in an atmosphere of $95 \%$ air and $5 \% \mathrm{CO}_{2}$, medium was changed every $12 \mathrm{~h}(14,15)$. At day 3 of culture, cells were incubated for $24 \mathrm{~h}$ with AZT $\left(10^{-5} \mathrm{M}\right)$, ACTH $\left(10^{-9} \mathrm{M}\right)$ or doxorubicin $\left(10^{-6} \mathrm{M}\right)$. Control cultures were incubated without chemicals. Medium was collected and stored at $-80^{\circ} \mathrm{C}$. Some culture dishes had $10^{-5} \mathrm{M}$ BrdU in the medium during the last $12 \mathrm{~h}$ of incubation.

Hormone assay. Aldosterone and corticosterone plasma concentrations were measured by RIA, using commercial kits (Active Aldosterone and Rat Corticosterone RIAs, Diagnostic Systems Laboratories, Webster, TX ). The hormone concentrations in the incubation media were assayed by quantitative HPLC, as previously detailed (16-18).

Cell proliferation and apoptosis. Proliferating cells were identified by using the BrdU Labeling and Detection Kit I, and apoptotic cells by the Cell Death Detection Kit (Roche Diagnostics, Mannheim, Germany), according to the manufacturer's directions. Nuclei were stained with DAPI, and BrdU- and TUNEL-positive cells were detected by 
Table I. Effect of chronic AZT treatment on the morphometric parameters of rat $\mathrm{ZG}$ and $\mathrm{ZF}$.

\begin{tabular}{lcc}
\hline & Controls & AZT \\
\hline ZG & & \\
Volume of zona $\left(\mathrm{mm}^{3}\right)$ & $2.35 \pm 0.65$ & $2.57 \pm 0.71$ \\
Number of cells $\left(x 10^{3}\right)$ & $3.91 \pm 1.11$ & $4.02 \pm 1.26$ \\
Volume of cells $\left(\mu \mathrm{m}^{3}\right)$ & $539.4 \pm 65.2$ & $630.8 \pm 70.7$ \\
Volume of nuclei $\left(\mu \mathrm{m}^{3}\right.$ & $112.5 \pm 10.7$ & $140.2 \pm 15.5$ \\
ZF & & \\
Volume of zona $\left(\mathrm{mm}^{3}\right)$ & $16.85 \pm 5.2$ & $17.22 \pm 4.95$ \\
Number of cells $\left(\mathrm{x} 10^{3}\right)$ & $8.14 \pm 2.12$ & $8.26 \pm 2.44$ \\
Volume of cells $\left(\mu \mathrm{m}^{3}\right)$ & $1862.4 \pm 200.8$ & $2081.5 \pm 219.7$ \\
Volume of nuclei $\left(\mu \mathrm{m}^{3}\right)$ & $170.1 \pm 18.3$ & $198.2 \pm 21.6$ \\
\hline
\end{tabular}

Data are means $\pm \mathrm{SD}(\mathrm{n}=6) .{ }^{*} \mathrm{P}<0.05$ and ${ }^{* *} \mathrm{P}<0.01$ from the respective control value.

Table II. Effect of chronic AZT treatment on the stereological parameters of rat $\mathrm{ZG}$ and $\mathrm{ZF}$ cells.

\begin{tabular}{lcr}
\hline & Controls & \multicolumn{1}{c}{ AZT } \\
\hline $\begin{array}{l}\text { ZG } \\
\text { Volume of mitochondrial } \\
\text { compartment }\left(\mu \mathrm{m}^{3} / \text { cell }\right)\end{array}$ & $93.9 \pm 10.8$ & $111.9 \pm 12.2$ \\
$\begin{array}{l}\text { Surface area of mitochondrial } \\
\text { cristae }\left(\mu \mathrm{m}^{2} / \text { cell }\right)\end{array}$ & $1737.1 \pm 194.2$ & $2050.7 \pm 212.4$ \\
$\begin{array}{l}\text { Surface area of SER } \\
\left(\mu \mathrm{m}^{2} / \text { cell }\right)\end{array}$ & $3610.8 \pm 411.3$ & $4552.5 \pm 617.3$ \\
$\begin{array}{l}\text { Volume of lipid-droplet } \\
\text { compartment }\left(\mu \mathrm{m}^{3} / \text { cell }\right)\end{array}$ & $32.2 \pm 5.6$ & $14.5 \pm 3.1$ \\
$\begin{array}{l}\text { ZF } \\
\begin{array}{l}\text { Volume of mitochondrial } \\
\text { compartment }\left(\mu \mathrm{m}^{3} / \text { cell }\right)\end{array} \\
\begin{array}{l}\text { Surface area of mitochondrial } \\
\text { cristae }\left(\mu \mathrm{m}^{2} / \text { cell }\right)\end{array}\end{array}$ & $14215.3 \pm 1682.4$ & $15987.8 \pm 1805.2$ \\
$\begin{array}{l}\text { Surface area of SER } \\
\left(\mu \mathrm{m}^{2} / \text { cell }\right)\end{array}$ & $10239.0 \pm 1211.7$ & $14535.7 \pm 1782.2$ \\
$\begin{array}{l}\text { Volume of lipid-droplet } \\
\text { compartment }\left(\mu \mathrm{m}^{3} / \text { cell }\right)\end{array}$ & $253.8 \pm 36.2$ & $80.2 \pm 15.3$ \\
\hline
\end{tabular}

Data are means $\pm \mathrm{SD}(\mathrm{n}=6) .{ }^{*} \mathrm{P}<0.05$ and ${ }^{* *} \mathrm{P}<0.01$ from the respective control value.

double-fluorescence microscopy in a Leica DM-IRE2 inverted microscope. Proliferation and apoptotic rates were estimated by computer-assisted image analysis as the ratio between the number of BrdU- or TUNEL-positive nuclei and that of DAPI-stained nuclei (19-21).

Light and electron microscopy, and morphometry. Left adrenals of control and AZT-treated rats were halved. One half was fixed in Bouin solution overnight, embedded in

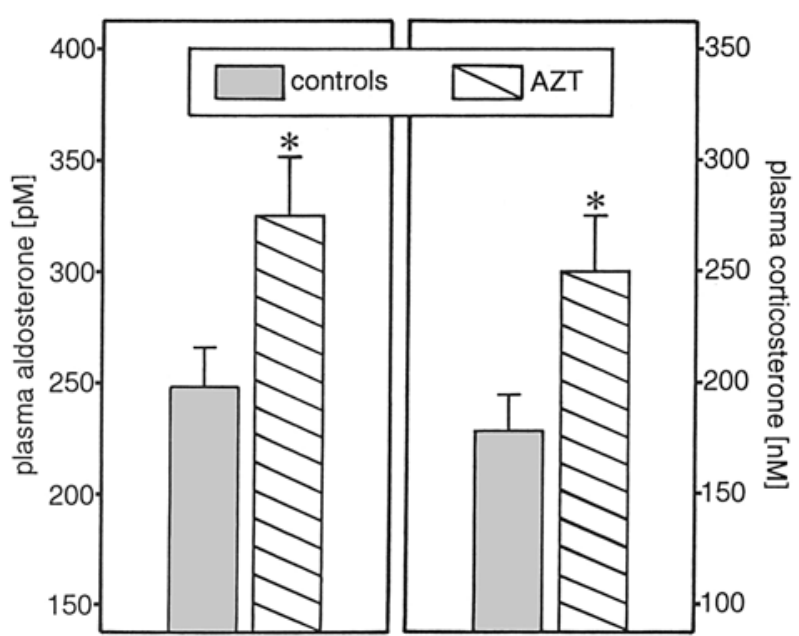

Figure 2. Effect of prolonged AZT admistration on the plasma concentration of aldosterone and corticosterone. Bars are means $\pm \operatorname{SEM}(n=8) .{ }^{*} \mathrm{P}<0.05$ from the respective control group.

paraffin and serially cut at a thickness of $6 \mu \mathrm{m}$ (17). Sliced pieces of the other half were fixed in $3 \%$ glutaraldehyde, postfixed in $1 \%$ osmium tetroxide, and embedded in epon $(17,22)$. Thick $(0.5 \mu \mathrm{m})$ and thin $(60-70 \mathrm{~nm})$ sections were cut with a LKB Supernova Ultrotome (Reichert-Jung, Vienna, Austria). Thin sections were counterstained with lead hydroxide, and examined and photographed in a Hitachi H-300 electron microscope. The volumes of zona glomerulosa (ZG) and zona fasciculata $(\mathrm{ZF})$, and the number and volume of their parenchymal cells, as well as the volume of nuclei were determined on light micrographs of paraffin and thick epon sections, as previously detailed (23). On the electron micrographs of ZG and ZF cells, the volume of the mitochondrial and lipid-droplet compartments, and the surface area per cell of mitochondrial cristae and smooth endoplasmic reticulum (SER) were evaluated by conventional stereological techniques (23).

Statistics. The data obtained were averaged per experimental group, and SD or SEM were calculated. The statistical comparison was carried out by ANOVA, followed by Duncan's multiple range test.

\section{Results}

Electron microscopy showed that AZT chronic administration did not produce appreciable qualitative alterations of rat adrenal morphologic features (Fig. 1) However, morphometry demonstrated that AZT caused an increase in the volume of $\mathrm{ZG}$ and ZF cells, and their nuclei without significantly affecting the volume of zones and the number of parenchymal cells (Table I). ZG and ZF cell hypertrophy was associated with sizeable increases in the volume of the mitochondrial compartment and in the surface area per cell of mitochondrial cristae and SER membranes. Conversely, the volume of the lipid-droplet compartment underwent a marked reduction (Table II; Fig. 1).

AZT administration induced a moderate, but significant rise in the plasma concentrations of aldosterone and corticosterone (Fig. 2). In vitro baseline and ACTH-stimulated aldosterone and corticosterone secretion from adrenal slices of 


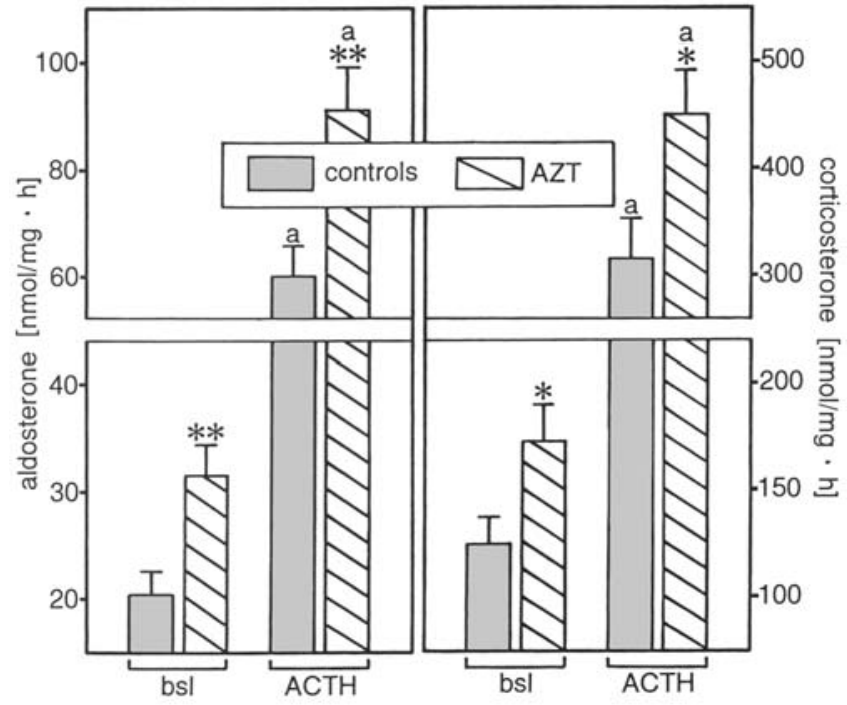

Figure 3. Effect of prolonged AZT administration on basal and ACTHstimulated aldosterone and corticosterone secretion from rat adrenal slices containing both ZG and ZF. Bars are means \pm SEM $(n=8) .{ }^{*} \mathrm{P}<0.05$ and ${ }^{* *} \mathrm{P}<0.01$ from the respective control value; ${ }^{\mathrm{a}}<0.01$ from the respective baseline (bsl) value.

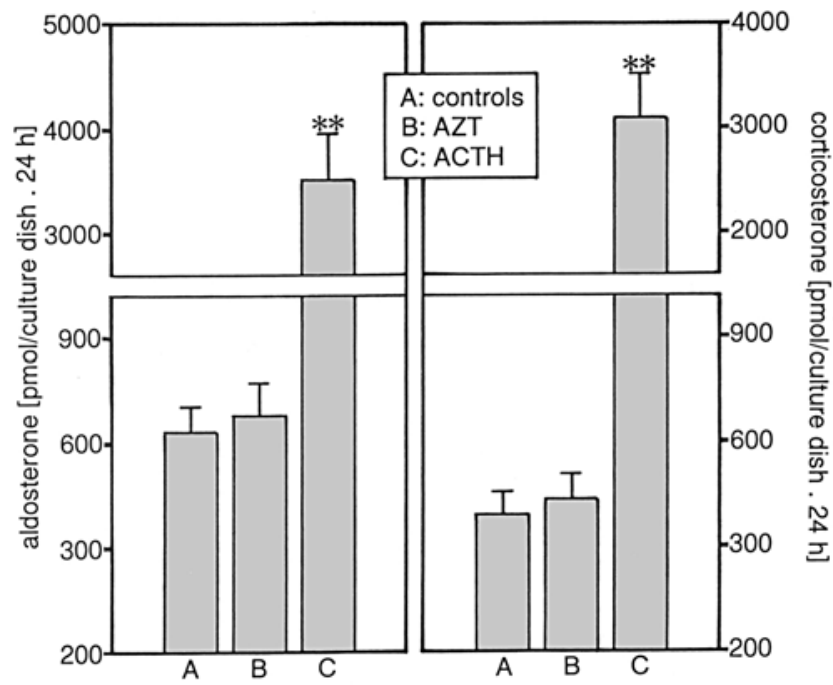

Figure 4. Effect of 24-h exposure to ACTH $\left(10^{-9} \mathrm{M}\right)$ and AZT $\left(10^{-5} \mathrm{M}\right)$ on aldosterone and corticosterone secretion from cultured rat adrenocortical cells Bars are means $\pm \operatorname{SEM}(\mathrm{n}=4) .{ }^{* *} \mathrm{P}<0.01$ from the respective control value.

AZT-treated rats were significantly higher than that of controls (Fig. 3).

As expected, adrenocortical-cell cultures exhibited a clearcut secretory response to ACTH (Fig. 4), and doxorubicin decreased the number of BrdU-positive cells and increased that of TUNEL-positive cells (Figs. 5 and 6). The 24-h exposure to AZT neither affected aldosterone and corticosterone secretion from cultured cells nor did it alter their proliferation and apoptotic indexes (Figs. 4-6).

\section{Discussion}

Our present study provides the first evidence that the prolonged treatment with AZT enhances the growth and secretory
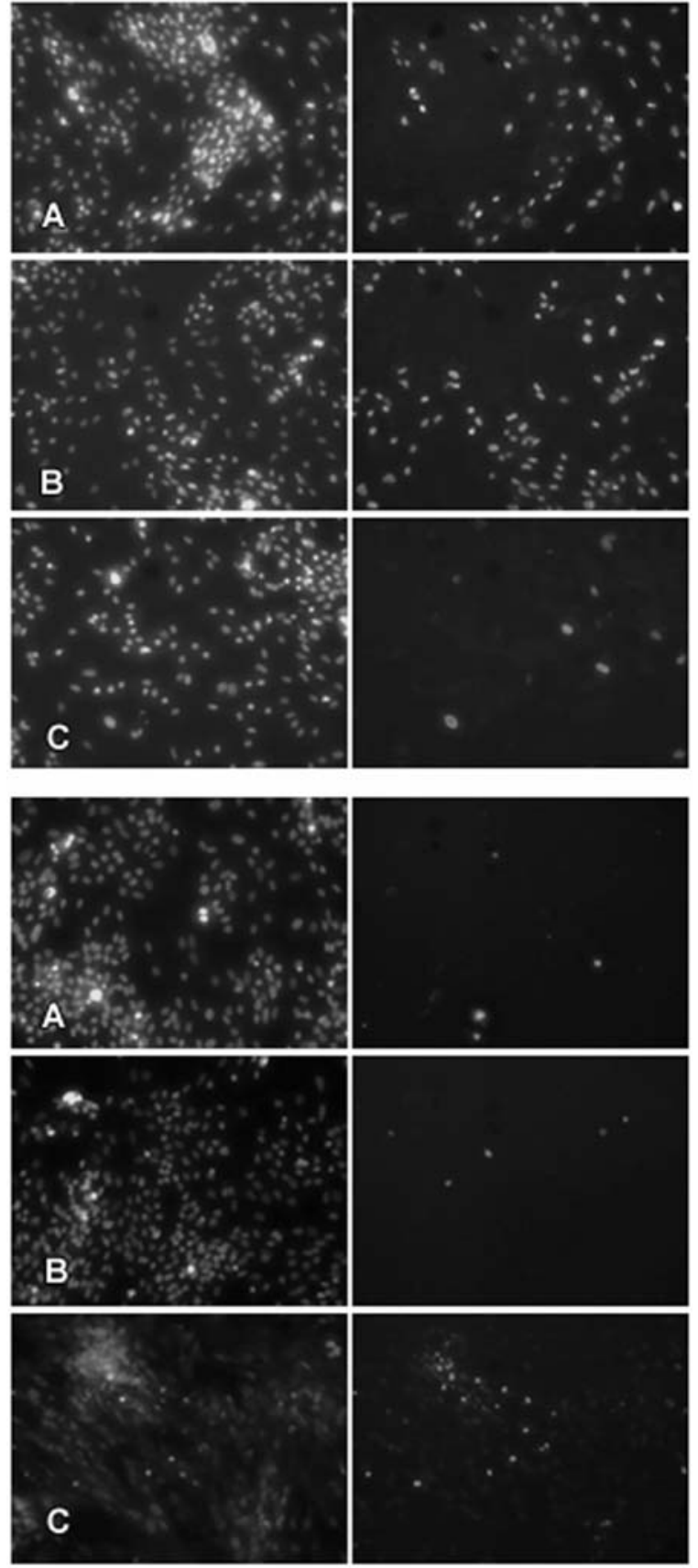

Figure 5. Fluorescein-labeled BrdU-positive (upper panel) and rodaminelabeled TUNEL-positive cells (lower panel) in control (A), AZT $\left(10^{-5} \mathrm{M}\right.$ )(B) and doxorubicine $\left(10^{-6} \mathrm{M}\right)$-treated (C) rat adrenocortical cell cultures. Respective total DAPI-positive cells are shown in left figures. AZT is ineffective, while doxorubicin decreases the number of BrdU-positive cells and markedly increases that of TUNEL-positive cells.

capacity of the rat adrenal cortex. This contention is based on both morphological and functional findings.

AZT treatment induces the hypertrophy of both ZG and $\mathrm{ZF}$ cells, which is coupled with increases in the volume of the mitochondrial compartment and SER. These morphologic data accord well with the rise in the blood levels of aldosterone and corticosterone, as well as with the enhancement of basal and ACTH-stimulated secretion of these hormones from adrenal slices containing ZG and ZF. Indeed, the enzymes of steroid synthesis are located in both mitochondria and SER (reviewed in refs. 24,25), and the changes 


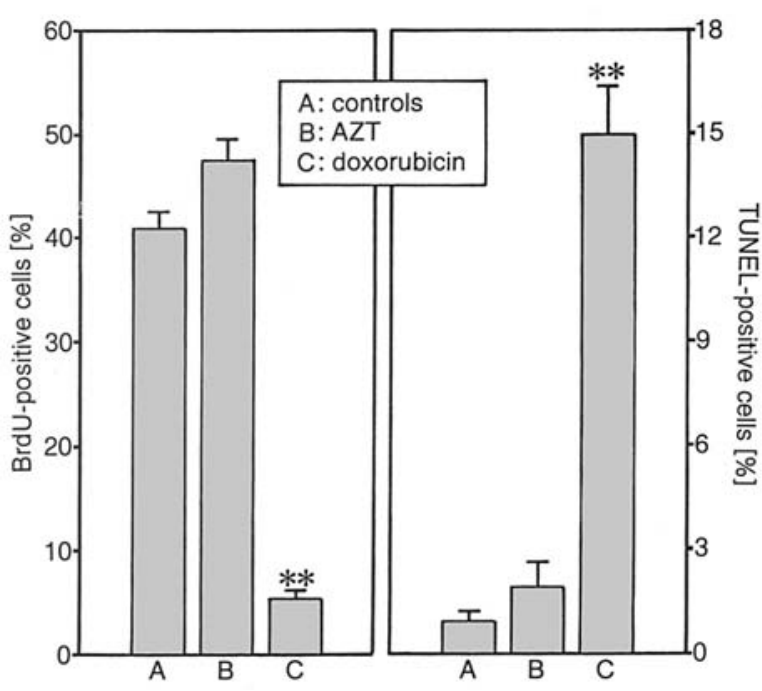

Figure 6. Effect of 24-h exposure to doxorubicin $\left(10^{-6} \mathrm{M}\right)$ and AZT $\left(10^{-5} \mathrm{M}\right)$ on the proliferation and apoptopic rates (percent number of BrdU-positive and TUNEL-positive cells) of cultured rat adrenocortical cells. Bars are means \pm SEM $(n=4) .{ }^{* *} \mathrm{P}<0.01$ from the respective control value.

in the surface area per cell of mitochondrial cristae and SER tubules were tightly coupled with corresponding changes in the activity per cell of some of these enzymes (reviewed in ref. 26). Also, the net decrease in the volume of the lipid-droplet compartment in adrenocortical cells of AZT-treated rats is compatible with an increased utilization of cholesterol in steroid synthesis, being commonly agreed that cholesterol and its esters are stored in adrenocortical lipid droplets (26-28).

The mechanism(s) underlying the moderate adrenal stimulating effect of prolonged AZT administration in rats remain(s) to be elucidated. A direct action of AZT on adrenocortical cells can be ruled out, inasmuch as the 24-h espoxure to this drug of cultured rat adrenocortical cells was ineffective (see below). ACTH is well known as the main physiological stimulator of adrenal growth (25). Sporadic findings indicate that ACTH blood levels are slightly over the control value in HIV patients (6), but it is not clear whether or not patients received antiretroviral therapy. Studies are needed to ascertain the possibility that AZT stimulates the central CRH/ACTH branch of the hypothalamic-pituitary-adrenal axis.

Before concluding, it is to be reminded that AZT does not provoke disruption of adrenal morphology or alter proliferation and apoptosis in cultured adrenocortical cells. These observations are rather unexpected because this drug causes evident mitochondrial alterations (swelling) in cardiomyocytes (see Introduction), and decreases proliferation rate and induces apoptosis in the mammalian carcinoma cell line T-47 D and cultured human placental cells $(29,30)$. It is probable that the differences in the susceptibility to AZT among different cells accounts for these discrepancies. It is to be recalled that there is evidence that cytotoxic effects of AZT depend on the rise in the ROS production $(10,12,30-32)$. Accordingly, the treatment with the anti-oxidant vitamin $\mathrm{C}$ is able to prevent AZT-induced toxic lesions in rat cardiomyocytes $(10,12)$. The adrenal gland is one of the organs with the highest concentration of vitamin $\mathrm{C}$ in the mammalian body (33), which not only is a cofactor required for both steroid-hormone and catecholamine synthesis, but also prevents the destructive effects of lipid peroxidation on adrenocortical mitochondria cytocrome P450 (34-36). Hence, it is possible that the high level of vitamin $\mathrm{C}$ preserves adrenocortical cells from the deleterious effects of the AZT-induced increase in intracellular ROS production.

\section{References}

1. Eledrisi MS and Verghese AC: Adrenal insufficiency in HIV infection: a review and recommendations. Am J Med Sci 321: 137-144, 2001.

2. Hoshino Y, Yamashita N, Nakamura T and Iwamoto A: Prospective examination of adrenocortical function in advanced AIDS patients. Endocr J 49: 641-647, 2002.

3. Mayo J, Collazos J, Martinez E and Ibarra S: Adrenal function in the human immunodeficiency virus-infected patient. Arch Int Med 162: 1095-1098, 2002.

4. Horowitz E, Miller JL and Rose LI: Transient adrenocortical insufficiency in AIDS. Am J Med 91: 440, 1991.

5. Christeff N, Gharakhanian S, Thobie N, Rozenbaum W and Nunez EA: Evidence for changes in adrenal and testicular steroids during HIV infection. J Acquired Immune Defic Synd 5: 841-846, 1992.

6. Biglino A, Limone P, Fozno B, Pollono A, Cariti G, Molinatti GM and Gioannini P: Altered adrenocorticotropin and cortisol response to corticotropin-releasing hormone in HIV-1 infection. Eur J Endocrinol 133: 173-179, 1995.

7. Kaiser P and Nassar N: Abacovir sulfate/lamivudine/zidovudine fixed combination in the treatment of HIV infection. Expert Opin Pharmacother 8: 477-483, 2007.

8. Lamperth L, Dalakas MC, Dagani F, Anderson J and Ferrari R: Abnormal skeletal and cardiac muscle and mitochondria in human muscle in vitro and in an animal model. Lab Invest 65: 742-751, 1991.

9. Domanski MJ, Sloas MM, Folimann DA, Scalise PP, Tucker EE, Egan D and Pizzo PA: Effect of zidovudine and didanosine treatment on heart function in children infected with human immunodeficiency virus. J Pediatr 127: 137-146, 1995.

10. Garcia de la Assunction J, Del Olmo ML, Sastre J, Millan A, Pellin A, Pallardo FV and Viña J: AZT treatment induces molecular and ultrastructural oxidative damage to muscle mitochondria. Prevention by antioxidant vitamins. J Clin Invest 102: 4-9, 1998.

11. Ruga E, Bova S, Nussdorfer GG, Mazzocchi G, Rebuffat P, Milanesi $\mathrm{O}$ and Cargnelli G: Zidovudine-induced alterations in the heart and vascular smooth muscle of the rat. Cardiovasc Res 60: 147-155, 2003.

12. Papparella I, Ceolotto G, Berto L, Cavalli M, Bova S, Cargnelli G, Ruga E, Milanesi O, Franco L, Mazzoni M, Petrelli L, Nussdorfer GG and Semplicini A: Vitamin C prevents zidovudine-induced NAD(P)H oxidase activation and hypertension in the rat. Cardiovasc Res 73: 432-438, 2007.

13. Neri G, Bova S, Malendowicz LK, Mazzocchi G and Nussdorfer GG: Simulated microgravity impairs aldosterone secretion in rats: possible involvement of adrenomedullin. Am J Physiol 283: R832-R836, 2002.

14. Albertin G, Casale V, Ziolkowska A, Spinazzi R, Malendowicz LK, Rossi GP and Nussdorfer GG: Urotensin-II and UII-receptor expression and function in the rat adrenal cortex. Int J Mol Med 17: 1111-1115, 2006.

15. Spinazzi R, Ziolkowska A, Neri G, Nowak M, Rebuffat P, Nussdorfer GG, Andreis PG and Malendowicz LK: Orexins modulate the growth of cultured rat adrenocortical cells, acting through type 1 and type 2 receptors coupled to the MAPK p42/p44- and p38-dependent cascades. Int J Mol Med 15: 847-852, 2005.

16. Neri G, Malendowicz LK, Andreis PG and Nussdorfer GG: Thyrotropin-releasing hormone inhibits glucocorticoid secretion of rat adrenal cortex: in vivo and in vitro studies. Endocrinlogy 133: 511-514, 1993.

17. Neri G, De Toni R, Tortorella C, Rebuffat P, Bova S, Cargnelli G, Petrelli L, Spinazzi R and Nussdorfer GG: Ouabain chronic infusion enhances the growth and steroidogenic capacity of rat adrenal zona glomerulosa: the possible involvement of the endothelin system. Int J Mol Med 18: 315-319, 2006. 
18. Spinazzi R, Petrelli L, Guidolin D, Carraro G, Casale V, Tortorella C, Neri G, Albertin G, Andreis PG and Nussdorfer GG: In vitro culture on Matrigel favors the long-term maintenance of rat zona glomerulosa-cell differentiated phenotype. Int J Mol Med 17: 1101-1110, 2006.

19. Andreis PG, Malendowicz LK, Trejter M, Neri G, Spinazzi R, Rossi GP and Nussorfer GG: Ghrelin and growth hormone secretagogue receptor are expressed in the rat adrenal cortex: evidence that ghrelin stimulates the growth, but not the secretory activity of adrenal cells. FEBS Lett 536: 173-179, 2003.

20. Conconi MT, Baiguera S, Guidolin D, Furlan C, Menti AM, Vigolo S, Belloni AS, Parnigotto PP and Nussdorfer GG: Effects of hyperbaric oxygen on proliferative and apoptopic activities and reactive oxygen species generation in mouse fibroblast 3T3/J2 cell line. J Investig Med 51: 227-232, 2003.

21. Andreis PG, Rucinski M, Neri G, Conconi MT, Petrelli L, Parnigotto PP, Malendowicz LK and Nussdorfer GG: Neuropeptides B and W enhance the growth of human adrenocortical carcinoma-derived NCI-H295 cells by exerting MAPK p42/p44-mediated proliferogenic and antiapoptotic effects. Int J Mol Med 16: 1021-1028, 2005.

22. Albertin G, Carraro G, Petrelli L, Guidolin D, Neri G and Nussdorfer GG: Endothelin-1 and adrenomedullin enhance the growth of human adrenocortical carcinoma-derived SW-13 cell line by stimulating proliferation and inhibiting apoptosis. Int $\mathrm{J}$ Mol Med 15: 469-474, 2005.

23. Rebuffat P, Kasprzak A, Andreis PG, Mazzocchi G, Gottardo G, Coi A and Nussdorfer GG: Effects of prolonged cyclosporine-A treatment on the morphology and function of rat adrenal cortex. Endocrinology 125: 1407-1413, 1989.

24. Ishimura K and Fujita H: Light and electron microscopic immunocytochemistry of the localization of adrenal steroidogenic enzymes. Microsc Res Techn 36: 445-453, 1997.

25. Spät A and Hunyady L: Control of aldosterone secretion: model for convergence in cellular signaling pathways. Physiol Rev 84: 489-539, 2004.

26. Nussdorfer GG: Cytophysiology of the adrenal cortex. Int Rev Cytol 98: 1-405, 1986.
27. Mazzocchi G, Robba C, Meneghelli V and Nussdorfer GG: Effects of ACTH and aminogluthetimide administration on the morphological and functional reponses of rat adrenal zona fasciculata to a prolonged treatment with 4-aminopyrazolopyrimidine. J Anat 154: 55-61, 1987.

28. Toth IE, Szabo D and Bruckner GG: Lipoproteins, lipid droplets, lysosomes, and adrenocortical steroid hormone synthesis: morphological studies. Microsc Res Techn 36: 480-492,1997.

29. Mediavilla M and Sanchez-Barcelo EJ: Dose and time-dependent effect of 3'-azido-3'-deoxythymidine on T47 D human breast cancer cells in vitro. Pharmacol toxicol 87: 138-143, 2000.

30. Collier AC, Helliwell RJA, Keelan JA, Paxton JW, Mitchell MD and Tingle MD: 3'-azido-3'- deoxythymidine (AZT) induces apoptosis and alters metabolic enzyme activity in human placenta. Toxicol Appl Pharmacol 192: 164-173, 2003.

31. Szabados E, Fischer GM, Toth K, Csete B, Nemeti B, Trombitas K, Habon T, Endrei D and Sumegi B: Role of the reactive oxigen species and poly-ADP-ribose polymerase in the development of AZT-induced cardiomyopathy in rat. Free Radical Biol Med 26: 309-317, 1999.

32. Valenti D, Atlante A, Barile M and Passarella S: Inhibition of phosphate transport in rat heart mitochondria by3'-azido-3'deoxythymidine due to stimulation of superoxide anion mitochondrial production. Biochem Pharmacol 64: 201-206, 2002.

33. Deane HW: The anatomy, chemistry, and physiology of adrenocortical tissue. In: The Adrenocortical Hormones. Their Origin, Chemistry, Physiology and Pharmacology. Part 1. Deane HW (ed). Springer Verlag, Berlin pp1-185, 1962.

34. Hoznsby PJ, Harris SE and Aldern KA: The role of ascorbic acid in the function of the adrenal cortex: studies in adrenocortical cells in culture. Endocrinology 117: 1264-1271, 1985.

35. Staats DA and Colby HD: Modulation of the effects of ascorbic acid on lipid peroxidation by tocopherol in adrenocortical mitochondria. J Steroid Biochem 32: 609-611, 1989.

36. Patak P, Willenberg HS and Bornstein SR: Vitamin C is an important cofactor for both adrenal cortex and adrenal medulla. Endocr Res 30: 871-875, 2004. 